慶應義塾大学学術情報リポジトリ

Keio Associated Repository of Academic resouces

\begin{tabular}{|c|l|}
\hline Title & Immunohistochemical localization of metallothionein in the eye of rats \\
\hline Sub Title & \\
\hline Author & $\begin{array}{l}\text { 小林, 静子(Kobayashi, Shizuko) } \\
\text { 西村, 久雄(Nishimura, Hisao) } \\
\text { 西村, 典子(Nishimura, Noriko) } \\
\text { 遠山, 千春(Toyama, Chiharu) }\end{array}$ \\
\hline Publisher & 共立薬科大学 \\
\hline Publication year & 1991 \\
\hline Jtitle & $\begin{array}{l}\text { 共立薬科大学研究年報 (The annual report of the Kyoritsu College of } \\
\text { Pharmacy). No.36 (1991.),p.51-51 }\end{array}$ \\
\hline JaLC DOI & \\
\hline Abstract & \\
\hline Notes & 抄録 \\
\hline Genre & Technical Report \\
\hline URL & https://koara.lib.keio.ac.jp/xoonips/modules/xoonips/detail.php?koara_id=AN00062898-0000003 \\
& 6-0051 \\
\hline
\end{tabular}

慶應義塾大学学術情報リポジトリ(KOARA)に掲載されているコンテンツの著作権は、それぞれの著作者、学会または出版社/発行者に帰属し、その権利は著作権法によって 保護されています。引用にあたっては、著作権法を遵守してご利用ください。

The copyrights of content available on the KeiO Associated Repository of Academic resources (KOARA) belong to the respective authors, academic societies, or publishers/issuers, and these rights are protected by the Japanese Copyright Act. When quoting the content, please follow the Japanese copyright act. 


\title{
Immunohistochemical localization of metallothionein in the eye of rats*
}

\author{
Shizuko Kobayashi, Hisao Nishimura**, Noriko Nishimura** \\ and Chiharu ToHYAMA*** \\ 小林静子, 西村久雄 ${ }^{* *}$, 西村典子**, 遠山千春***,
}

Metallothionein (MT) is a group of low molecular weight proteins, with a unique amino acid composition such as a large content (approximately 30\%) of cysteine residues, which endows MT with a very high affinity for heavy metals such as zinc $(\mathrm{Zn})$, copper $(\mathrm{Cu})$ and cadmium. Another unique property of MT is the inducibility upon exposure to these heavy metals as well as in response to various endogenous factors. MT is present in various biological species, and is always found to contain $\mathrm{Zn}$ ions, supporting the idea that MT may be associated with essential physiological roles by storage and supply of $\mathrm{Zn}$ ions.

If MT is closely associated with $\mathrm{Zn}$ metabolism, the protein is expected to be localized in tissues that are abundant in $\mathrm{Zn}$ ion. In fact, MT is localized in Paneth cells of small intestine and in the dorsolateral lobes of prostate, the tissue which are known to be rich in $\mathrm{Zn}$. Futhermore, MT concentrations were found to parallel with $\mathrm{Zn}$ concentrations in actively proliferating and differentiating tissues such as those under development stages and partially hepatectomized rat liver. In the eye, the presence of a protein similar in physiochemical properties to MT was found in the extract from the bovine retina in which relatively large amounts of $\mathrm{Zn}$ ions are present. Thus, in the present study, using an immunohistochemical technique, we have investigated characteristic localization of MT in various tissues of the eye of rats and also discussed a possible link of MT with physiological processes.

As a result, strong MT immunostaining was observed in the epithelium of the lens and cornea. In the retina, considerably strong MT immunostaining was observed in the pigment cell layer while the nervefiber layer and inner plexiform layer showed weak MT staining. Glial cells in the optic nerve were found to have marked MT staining. The present result is consistent with the hypothesis that MT may be involved not only in activation of $\mathrm{Zn}$ enzymes and cell proliferation through supply of $\mathrm{Zn}$ ions, but also in a protective mechanism in the blood-retina barrier.

\footnotetext{
* 本報告は Histochemistry，95，535-539（1991）に発表.

** 愛知医大衛生学教室

*** 国立環境研究所
} 